\title{
An empirical study discussing industrialisation and technical education in Ghana
}

\author{
Martin Donani ${ }^{1 *}$, Rhoda Saan ${ }^{2}$, Frederick Kuuyine ${ }^{1}$ and Yunus Adams ${ }^{1}$ \\ ${ }^{1}$ Mechanical Engineering Department, Faculty of Engineering, Dr. Hilla Limann Technical University, Wa, Upper West \\ Region, Ghana. \\ ${ }^{2}$ Department of Liberal and General Studies, Director of Entrepreneurship and Business Innovation, School of Applied \\ Art, Design and General Studies, Dr. Hilla Limann Technical University, Wa, Upper West Region, Ghana.
}

Received 29 January, 2021, Accepted 18 June, 2021

\begin{abstract}
Industrialisation generally accounts for wealth creation in the economy of a nation. A technician is needed in building an industry and the technician needs to be trained through technical education. Ghana as a developing nation aspiring to develop her industrial capability needs to strategically position its technical education as a key factor. The objective of this paper therefore is to review Ghana's industrialisation agenda and its technical educational system toward establishing an industrial base as a future cultural heritage. The soft operations methodology of ethnography, which is gaining much popularity in Production and Operations Management (POM), was adapted for this study. The findings, among other things, revealed a high interest in industrialising the Ghanaian economy, which is characterised by an absence of a policy framework for technology development to feed the industry. This is coupled with a disconnection of formal education from application of indigenous knowledge in production methods. This therefore calls for a policy-shift to build a comprehensive technical and vocational education and training (TVET) curriculum with linkage to culture for industrial growth.
\end{abstract}

Key words: Technical education, industrialisation, development, training, economy.

\section{INTRODUCTION}

This is an inductive study on industrial development in Ghana. The study argues that culture is relevant to industrialisation, and technical education could serve as the propelling vehicle to drive the long aspired industrialisation agenda in Ghana to its realisation. Ghana, like other African countries, has long aspired to develop its industrial capability. Ever since her political independence from its British colonial rulers to date, such aspiration still remains a wish. The question this paper hopes to answer is; can technical education be used to spur Ghana's industrialisation intent through a culturally focused approach/inclusion?

Based on the Production and Operations Management (POM), this paper stretches the study outside the production factory floor of operations management to seek answers to the industry lag in Ghana. POM is home

\footnotetext{
*Corresponding author. E-mail: yawmat@hotmail.com.
} 
to industry, thus, making this study to be highly relevant both for its expansion (into African industries) and its sustainability.

The study begins with an attempt to understand the industrial lag in the Ghanaian economy. It further highlights the strategic positioning of technical education as a means to accelerate the industrialisation intent of Ghana, noting the significance of culture (indigenous production systems) in industrialisation as a neglected component. This study therefore adopted a multidisciplinary approach, outspreading beyond the traditional boundaries of POM research methods. Embedded in the study, however, is the questioning approach to problem solving typically employed in operations management. Here, the industrialisation lag in Ghana, and by extension, Africa, is considered as the problem of discussion.

The ethos of this paper, in brief, is to generate a discussion for policy implication in Ghana (and where applicable) on the stalled industrial development, which generally accounts for the lag, hence, technology gap. Industrialisation, here, is concomitant with technology development; thus, both terminologies may be used interchangeably in this paper.

Technology, according to Slack et al. (2010) and Khalil (2000), is defined as the resource, tool, knowledge and processes used in transforming raw materials to a desired end. Technology is here seen as the essential tool that makes it possible to competitively (economically, efficiently and profitability) transform raw materials into finished goods to expected quality. The vibrancy and strength of a national economy, throughout history, is associated with its ability to use technological solutions efficiently to effectively address industrial challenges (Edgerton, 2008). This paper opined that all industry require the use of technology. The use of technology applies both to the production of goods and the provision of services.

On the contrary, however, African nations (of which Ghana is inclusive) are almost left out of the loop of selfinitiated advancing technological solutions, development, deployment and adaptation. Previous scholars have shown how African countries, in their effort to industrialise adopted similar development models that proved successful in other developing regions of the world, notably in Asia and Latin America (Edgerton, 2008; Lall and Kraemer-Mbula, 2005). Those policy models, such as import substitution failed to yield the same positive results in Africa (Chevalier et al., 1992). The case of Africa is therefore unique; being selective in adopting to prevailing technologies (Austin and Headrick, 1983) and failing to respond to the stimuli for technical change (Lall and Kraemer-Mbula, 2005). The persistent disappointing results (of conventional development models employed in
Africa) led to scholars calling for a debunking of these development models, which are mainly of non-African origin (Chevalier et al., 1992; Portes, 1976). An African technology development model was therefore constructed to suite the African mixed cultural setting with focus on Ghana (Donani et al., 2017a). The Model allows the development intent to "rhyme" with the mixed culture of the Ghanaian society.

\section{Industrialisation and culture}

Human survival is depicted by culture and all through history, various levels of technology have been in use to spur societal development. Technological change (discovery, adaptation and advancement), invariably, marks the evolution of human civilisation as expressed by Khalil (2000). Furthermore, technology historians like Edgerton (2008), Austin and Headrick (1983) and others have established a strong link between a people's way of life (culture) and their technological and industrial developments.

Scholars have indeed shown that people's mindset is "programmed" by their cultural disposition (Hofstede, 2013). Culture has been defined by Davidson et al. (1965) as people's way of life. By this reasoning therefore, if a given people's way of life (culture) does not "match" a particular pattern (e.g., industrialisation as being discussed here) then the introduction of such "pattern" into the setting is more likely to suffer and probably fail. This has indeed been the industrial narrative in Ghana. Culture, therefore, becomes the underpinning factor in consideration for an industrial base as shown in the work of Gertler (2004). The focus here is not a specific Ghanaian culture, but using culture as a platform for discussion.

\section{Ghana's industrial gap}

There is undeniable technological/industrial gap between Africa and the advanced world. Indeed, it has been noted by scholars that the African development performance, in comparison to the rest of the world, remains at the bottom of the "scoreboard" (Lall and Kraemer-Mbula, 2005). The authors further stated that the industrial gap between Africa and other advancing countries was rather widening. Take for example, Cruickshank and Richardson (2019) who showed that an advancing country like South Korea (using the technology penetration indicators, such as; the competitive industrial performance (CIP) index) in 2016 was ranked $4^{\text {th }}$ on the "industrial scale" as compared to Ghana, which was ranked $119^{\text {th }}$. Cruickshank and Richardson (2019) further 
showed that, by 2015, Ghana was, in terms of gross domestic product (GDP) per capita, where South Korea was in 1985, even though, Ghana's GDP was higher in the 1960s. Over time, Ghana had fallen thirty years behind with the gap even bigger now. South Korea seems to have exploited its technical capabilities, while Ghana is just realising its technical potentials to develop same.

\section{Technical education for industrialisation}

Technical education, as the name implies, pivots education on technical competence and applications. This includes all technical and vocational trades as defined by UNESCO (2002) shown by Effah (2017). Technical education is a necessary actor, as shown in the field of e-learning (Chatelier and Voicu, 2018) for the thriving and continuity of industrialisation for societal survival and advancement (COTVET, 2016). To initiate and sustain a growth in the industrial drive, the role of Technical Education becomes highly relevant. It builds the needed technical minds necessary to provide the national human resource that will continuously attend to the technical needs in industry (Donani, 2015a).

The educational sector in Ghana has gone through a number of reforms as explored in this study. The reforms are well applauded, however, scholars have shown that the educational system is rigid (CMEAU, 2007) and displays a disconnection from tradition and culture (Ndiaya and Lv, 2018; Donani et al., 2017b). Culture cannot be overruled in industrialisation pursuit as shown by Gertler (2008) in his work while looking at the Canadian manufacturing industry.

This paper, thus, argues that industrialisation is highly cultural, and wishes to employ technical education as a medium of linkage for accelerated industrial growth. The aim of this study therefore is to highlight the connectivity between industrialisation and culture and suggest that technical education could bridge the disconnection seen in formal education and application of indigenous knowledge in production towards industrialisation.

\section{THEORETICAL BACKGROUND}

Ghana's economy has been described by scholars as being fragile since pre- and post-colonial regimes (Aryeetey and Fosu, 2008). The authors alluded that the fragility was mainly due to the dependency of the economy almost entirely on export of primary produce and sporadic capital injection from donor nations. This suggests that the national economy is hardly independent to carry out its initiative towards development, even though endowed with vast amount of natural resources (Economywatch-Content, 2010), which are exported in the primary state without value-addition (Juma, 2011).
Technology application is required at all levels in the process of transforming primary produce for added value. The developing world, however, of which Ghana is one, is generally characterised by a technology lag (Lall and Pitroballi, 2002). Akubue (2000) elaborated on the huge influx of capital-intensive technologies into the developing world. It is however inexplicable how this huge influx has not translated to technical change in the African industrial landscape despite the extensive exposure to modernisation. Indeed, Teal (1998) argued that the prevalence of a lack of diversification in the manufacturing sector in Ghana significantly weakened the technology base for transformative purposes. He opined that the manufacturing firms were easy to fall out, in the light of a weak industrial base. The firms are unable to compete effectively with their counterparts from the developed world and other rapidly advancing countries (Lall and Pitroballi 2002). In alignment with Lall and Pitroballi (2002), Mayer (2004) considered the significant role of foreign investors towards building an industrial economy. The author highlighted how, at any time, investors could shift their production base to more favourable regions of the world, hence, the fragility of the developing world. This calls for emphasis on building domestic industrial base.

The manufacturing industry, according to UNIDO (2017), stands as the pivot to the industrialisation of an economy. Indeed, the work of Ndiaya and Lv (2018) on the Senegalese economy demonstrated that industrialisation remains the most essential component for a country's economic growth. This claim is strengthened by the work of Signé and Johnson (2018), which states that, "While policy solutions are likely to differ across countries, manufacturing and industrial development will be central to Africa's ability to meet its development goals". The bane however, according to the African Development Bank, is; "...African economies have deindustrialized" (ADB, 2019). Industrialisation in Africa appears not to be initiated by Africans (Donani et al., 2017a). This implies that industrialisation is "alien" to the African way of life (culture). It is not historically considered as a cultural heritage on the African scene (Cossart, 2020) when large-scale commercial enterprise is to be mentioned.

\section{Culture and people}

The subject of culture is hardly discussed in POM. This paper, though not a study on culture, on the other hand, aims to use culture as a platform for discussion with the specific aim to highlight its key role in industrialisation. This section is an attempt to establish a common ground of understanding of what culture is and its relevance to the subject of discussion, that is, industrialisation. This is to serve as a framework for the construction of the industrial narrative of the Ghanaian economy to aid the 
discussion on Ghana's industrial lag.

Cultural variance could be seen as the way in which different groups of people from different societies (including organisations and firms), perceive the world and respond to its events (Cossart, 2020; Hofstede, 1984). Hofstede (2011) expounded on the concept of cultural dimensions as a way to understand behaviours from different groupings. Wolcott (1990)'s work demonstrated the essence in cultural inclination as it defines a people's mode of life and orientation.

As noted by Hofstede (2013), culture is the unwritten rules found in every human grouping. In his work, Hofstede found that culture varied and accounted for the way people think and why they react differently to the same set of stimuli. Thus, Hofstede in stating that, "culture is reflected in the meanings people attach to various aspects of their life; their way of looking at the world... ....and how they react to its challenges", suggests that culture leads to a value system. This value system becomes an issue of interest here in determining the value placed on industrialisation for a traditional setting as a future cultural heritage. The question is, how is the Ghanaian society culturally inclined towards industrialisation?

\section{Defining culture}

There are volumes of publications on the subject of culture, as such; in-depth discussion may be suspended here. This section will however, attempt to establish a common ground definition of culture for the discussion of this subject. Scholars on the topic are confronted with the difficulty of coming to a single definition for culture. Several definitions therefore exist, often depending on the area of cultural interest that the author may have. According to Adam and Cohen (2009), culture is placed under two broad categories. One group of definition sees culture as the search for meaning, whereas the other group's definition focuses on information or knowledge. The former has to do with values, morals, and the latter is considered to relate to artefacts of culture, looking at its evolution in the use of tools (costumes, cookery, implements, machine, among others). Adam and Cohen (2009) observed that what is called culture is influenced by who studies it. In other words, its understanding is subjective to the observer's perception, hence, its interpretation. Yet within such limitation, the existence of a commonality in behaviours within the setting of a particular society may be conclusive.

Owing to the divergent views among authors, the understanding of culture engendered in this study in consolidation with the work of previous scholars may here be defined as; a set of behavioural commonalities in perception, belief and conduct that identifies a people resulting in the acceptance or rejection of values. Values here refer to the item/concept of consideration. The culture of a people would therefore determine their behaviour (as in interest or otherwise) in relating to an event or ideology. Authors' divergence on the topic is found to, at least, converge on one point, that culture is variedly defined with its social reality of unevenness (Hall, 1980), which makes its study even more relevant in acceptance or rejection of an agenda like the industrialisation subject of this paper. Culture evolves (Donani, 2017b) and could be instilled through the technical educational system.

\section{Technical education in Ghana}

Technical education is conjoined with vocational education and together referred to as, technical and vocational education and training (TVET). In Ghana, TVET begins from an informal level, cutting into mainstream educational system. The post-primary level at the Junior High School (JHS) begins its formal ascent. There students are acquainted with both technical and non-technical subjects. The students are to make the choice whether to carry-on with the academic line for progression, or take up a position in the world of work (as in technical or vocational career). Technical and vocational career pathways were intended to prepare students for the world of work, as defined by UNESCOUNEVOC (2012). The formal delivery of TVET expands through secondary education or its parallel level of technical schools in Ghana and parts of Africa to the tertiary level which comprises of the polytechnics and universities (Oketch, 2007), now, technical universities in Ghana (MoE, 2014).

There are attempts, therefore, to provide a more comprehensive TEVT form of education in contemporary Ghana (Effah, 2017). Effah (2017) went further to state that the reforms were laudable, but the implementation had the potential of eroding the anticipated benefits it was meant to offer in development.

\section{Technical education and development}

According to COTVET (2016), "TVET serves as the springboard for the development of every country". It can therefore be unequivocally stated that the industrial development agenda of any nation requires due consideration to the strength and quality of its technical education, for the supply of the needed human technical resource to factories and industry.

The African Union acknowledges TVET "as an avenue for preserving and promoting indigenous knowledge and skills, particularly in relation to traditional arts and craft" (African Union, 2007). Ghana's educational system, according to scholars, breeds elite engineers group, "whose skills, some soon atrophy" as it trains engineers on paper work, rather than on products (Cruickshank and 
Richardson 2019). A TVET conscious training should eradicate the training of "engineers on paper work" as TVET advocates for on-the-job-training.

\section{Upgrading of technical institutions in Ghana}

Indeed, TVET has a long history in contemporary Ghana. Since the pre- and post-independence era, successive Ghana governments, following the pattern of the colonial governments, placed a premium on education, especially technical education (Nyarko, 2011). According to the author, since the 1950s, technical institutions were established in Accra, Takoradi and Kumasi, to train the needed technicians and technologists for the accelerated development of the country, more specifically, for the mining and railway industry. Later, Ho and Tamale Technical Institutes were also established. Nyarko further revealed (as was found in accordance with a polytechnic technical report, MoE 2014), that "in 1963, the Accra, Takoradi, and Kumasi Technical Institutes were redesignated as polytechnics without any legal backing". $\mathrm{Ho}$ and Tamale Technical Institutes were subsequently similarly upgraded to the polytechnic status in 1984 and 1986 respectively, with Cape Coast Polytechnic being established from inception. These institutions were however non-tertiary in their structure and delivery. They operated as second cycle institutions, unable to issue their own certificates as highlighted by Nyarko (2011).

The technical education structure then was also handicapped with the prospects of academic progression and rife with public stigmatisation and other challenges. According to the Bureau of African Ministers of Education, "the vocational education track has the unenviable reputation of being a dead end so far as academic progression is concerned and fit for those pupils who are unable to continue to higher education" (African Union, 2007). This has been the historic bane for those who choose the technical education line.

\section{Enacting the polytechnic laws to tertiary institutions}

Various Ghana Governments undertook a number of educational reforms and legislations to allay some of the setbacks associated with technical education in the country. Some of the reforms led Ghana to further upgrade the polytechnics to tertiary status.

In 1992, the Polytechnic Act was enacted to elevate the polytechnics to tertiary status (Effah, 2017; MoE, 2014; Nyarko, 2011). This was however done "without any upgrading in terms of facilities or staff" (Nyarko, 2011). In his recounting narrative, Nyarko expounded how other polytechnics where established across the country to ensure each of the then ten Regions of Ghana were provided with a polytechnic. These included the upgrading of Sunyani and Koforidua Technical Institute into a tertiary polytechnic status and construction of the Bolgatanga and Wa Polytechnics in 1999 and 2000, respectively as tertiary institutions. According to Effah (2017), "the conversion of the technical institutes into polytechnics was largely to ensure that there was progression for students who opted for the TVET stream."

The reforms in Ghana education with respect to TVET would be lauded as in the right direction with new and strategic programmes and interventions that are being rolled out. One of such structures being rolled out was the Council for Technical and Vocational Education and Training (COTVET) (COTVET, 2016). An Act of Parliament (Act 718) was passed in 2006 to establish the Council which was mandated to coordinate and oversee all aspects of TVET and skills development in the country (COTVET, 2016). The enactment of the TVET law in Ghana goes along with the development of the National Technical and Vocational Education Qualifications Framework (NTVETQF) that will harmonise all the various streams of TVET qualifications under a unified structure and certification system. Currently (at the time of writing this paper) TVET is "delivered by both government and private providers, which include for-profit institutions and non-profit, NGO and Church-based institutions" (African Union, 2007). UNESCO (2010) showed that the different delivery modes were offered by government ministries and agencies and without coordination to curtail the several stream-deliveries.

\section{Conversion of polytechnics to technical universities}

The polytechnics were inundated with pressing challenges, some of which were unclear mandate and national positioning, particularly in terms of parity with conventional universities in the country (Nyarko, 2011). Teachers at the polytechnics, though equally qualified, earned lesser than their university counterparts. This and other matters of disparity, like infrastructure led to unrest in the campuses (MoE, 2014).Prominent among the key arguments for the conversion was to "provide progression avenue for technical and vocational students and curb the growing phenomenon of academic-type "top-up" programmes for HND graduates at the traditional universities" (MoE, 2014).

In 2013, a nine-man committee was instituted to oversee the conversion after a presidential pronouncement in a state of the nation address to convert the polytechnics to technical universities (MoE, 2014). The committee was to advice government on the modality for the conversion process.

An Act of parliament, Act 922, was passed to convert the polytechnics to technical universities in 2016 from the set of criteria outlined by the committee. The universities are to "be modelled along the lines of Universities of Applied Sciences in Germany" (MoE, 2014). The technical universities, according to the Committee, among 
other things, should be practice oriented, train students for the world of work, have strong link with industry and business. This is intended to provide the human resource base for industrialisation.

\section{Ghana's industrialisation front}

Ghana, in her quest to industrialise, adopted a number of development models/policies aimed towards industrialisation. Some of such models include; import substitution, free zone enterprise, appropriate technology, technology transfer, dependency theory and others. Prominent among them is the import substitution. This section will discuss the import substitution briefly.

\section{Import substitution}

The aspiration desire for industrialisation has been a bane for Ghana's development since gaining political independence from their British colonial rulers on $6^{\text {th }}$ March, 1957. Pre-and post-independent Ghana has made significant efforts at establishing an industrially based economy (Amankwah-Amoah et al., 2018). Preindependence Ghana focused on exportation of cheap primary products in return for more expensive finished goods (dependency theory), whilst the later attempted to focus on value-addition through varied policy approach. Most prominent of them, as earlier mentioned, was the import substitution policy.

This policy, as shown in the work of Ackah et al. (2016), was considered most appropriate; because it was believed that it would help dispense with the distorting effects of the colonial system, escape from dependence on primary exports, and break the vicious circle of poverty".

According to Ackah et al. (2016), Ghana underwent three major episodes of industrialisation since her independence. The first was inward overprotected import substitution industrialisation from between 1965 to 1983. The second being an outward liberalised industrialisation strategy implemented between 1984 and 2000; and thirdly, industrial architecture based on value-added processing of Ghana's natural resource endowments through a private sector-led accelerated industrial development strategy.

The Ghana Industrial Policy document, produced by the Ministry of Trade and Industry (MoTI, 2009), highlighted such policies. The policy document, according to the Minister, was broad-based to embrace all stakeholders. The policy was drawn from the thematic areas presented by stakeholders, some of which include: industrial manpower development; financing for industrial development; land and infrastructure for industrial development; and others, including technology and innovation.
The policy, indeed, acknowledged the overall low level of science, technology, research and development innovation in industry. It went further to state that; "this limits the absorption and adaptation of modern technologies into the manufacturing sector, thus affecting its competitiveness". But the question that comes up is the issue of "adaptation of modern technologies"; how the issue of technology is being addressed? The policy was not found to attempt to address the technology question. This issue of technology remains neglected in African policies as stated by Lall and Pitroballi (2002) who stated that the issue of technology in African policies is hardly mentioned. Thus, technology matters were never addressed in the import substitution policies employed.

\section{Aftermath of Import substitution}

Import substitution policy is where factories are setup and production machineries are imported into the factory to produce such products as deemed necessary for the economy. These products, in the case of Ghana, are mainly consumer goods such as; groceries, plastic products, glass bottles, shoes, and the like. The machineries required for their large-scale production, are usually capital-intensive (Akubue, 2000; Edgerton, 2008; Donani, 2015b; Ackah et al., 2016). There was no such policy component to replicate the imported technologies or to reengineer the machineries (Cruickshank and Richardson, 2019). It was a policy of total reliance on imported technical solution, where spare parts are also imported.

In the event of an upgrade of a particular machine to the next generation, some of its parts also change, rendering the earlier version obsolete. Ackah et al. (2016) echoed the World Bank's assertion of how the import substitution policies "were not successful in achieving their intended objectives but instead formed incentives that created excess capacity and inadequate linkages with other growth enhancing sectors". The import substitution tends to favour the rich class who are engaged in manufacturing and supplying the technologies. Addressing the issue of technology therefore, Donani (2014 and 2015b), in his thesis constructed a model for Ghana's manufacturing of technology for industry.

\section{The technology factor}

Historically, Africa is noted to be selective in adopting prevailing technologies (Chakravorti and Chaturvedi 2019). For example, Cossart (2020) expressed how the African varied setting responded differently to adapting exogenous technological artefacts using the example of the gun. Similarly, Austin and Headrick (1983) noted that the invention of the wheel was historically not adopted in 
Africa, neither were any inventions recorded to emanate from Africa. Indeed, scholars have shown that the issue of technology and its subsequent development do not receive any significant attention in African policies (Amankwah-Amoah et al., 2018; Lall and Kraemer-Mbula, 2005). And that, "in the Ghanaian business community, technology is only conspicuous by its absence" (Lall and Pitroballie, 2002). This is also evidenced in the Ghana medium-term national development policy framework (GoG, 2010) document where no mention was given to technological solutions. It is argued, in agreement with like writers, that technology is central to any industrialisation approach (AMT, 2013; Edgerton, 2008). In Africa, however, the issue of technology is problematic despite the fact that initial data for development are often collated from the developing world (Szogs et al., 2009). Technological advancement for industrial application seems to be reserved for the advanced and advancing countries leaving out Africa.

The major industries in Ghana, which are mainly capital intensive are owned and controlled by foreign investors, as shown by Oxford Business Group (2020).

The need to develop domestic technology is essential for developing a country's industrial base (Ndiaya and Lv, 2018; Donani et al., 2017a). African policy of reliance on importation of technical solutions tends towards allowing for foreign cultural invasion. This study hence requires a culturally oriented research methodological approach in studying such matters as this. The next section therefore discusses the choice of suitable research methodology.

\section{METHODOLOGICAL APPROACH}

This study is considered to be sensitive, complex and highly problematic as it concerns the long standing and chronic issue of Ghana's industrialisation lag. Its tenets, indeed, cover the span of modern African history. The problem of Ghana, like the rest of Africa, still not having industrialised its economy, despite all the efforts by successive governments, makes it a unique situation requiring dedicated attention. As such; a suitable methodology for data collation and analysis will be sought or an appropriate one devised. A methodology that will not rely solely on deductions from numerical modelling and inferences to draw its conclusions (Collins and Stockton, 2018), but one that can give firsthand information is sought. This section therefore stretches the study beyond the natural boundaries of POM's research approaches to focus on humans as sources of data.

This section thus discusses the choice of the qualitative research methodology, ethnography, which was considered as the most practicable for such studies as this drawing on the work of Pelto, (2020). Its data collection methods such as participant observation, conversation and semi-structured interviews were found to be most suitable, thus employed to collect data from respondents on the ground. This is in addition to extensive literature reviewed. The detailed account of the methodology employed in this paper is outlined in the work of Donani (2014).

POM, as a problem-solving oriented discipline, employs a multidisciplinary approach in tackling issues ranging from a unit/section of a firm or factory to problems on a national scale (Tortorella et al., 2018; Kiridena and Fitzgerald, 2006; Coughlan and Coghlan, 2002). Researches in POM are therefore traditionally inclined towards research questions that lead to the use of numerals which are generated for analysis using a mathematical model or statistical methods (Barratt et al., 2011). These methods are found mainly in quantitative research approaches, generally described by authors in POM as hard operations.

Such hard core methodologies are not convenient for addressing certain research questions that cannot be expressed in numerical figures (Bernard, 2013). These are research questions that pose complex, textual (non-numerical) and human centred research problems. These are often simply referred to by POM scholars as ill-structured problems (Simon and Newell, 1958). Methodologies found in qualitative research approaches, here called, soft operations (Seagriff and Lord, 2008) are often employed in addressing ill-structured problems. One of such soft operations methodologies is ethnography, which was employed in this study.

Ethnography gives elaborate procedure to study the culture of a people or organisation, or where culture makes an entry (Wolcott, 1990), here, to understand the culture of Ghana's industrialisation and to position its technical education as a bridge. As a methodology, ethnography may however be faced with certain challenges. For example, the ethnographer views through the lens of informants, influenced by his/her own personal experience and cultural background. To mitigate such subjectivity, being a feature of qualitative researches (Barratt et al., 2011), a robust analytical tool for the corpus of data would be needed. As such, coding (invivo), as expressed in grounded theory (Corbin and Strauss, 1990) was employed. Narratives were therefore constructed from the data (Charmez, 2003), thus, reducing, if possible, eliminating the subjectivity inherent in reporting ethnographic findings (Gibbs, 2008).

\section{Ethnographic study}

Ethnography, by default, involves the researcher physically being present as a close observer or participant observer in retrieving firsthand information from respondents directly or through an informant. In addition to observation as a method for data collection, conversation, semi-structured and structured interviews were conducted over a period of one month and a week in both rural and urban settings. This involved living with the respondents in their locality and taking both written and digital voice records. Figure 1, with consent of participants, shows photographs of some of the interview sessions carried out.

In addition, semi-structured and structured interviews were conducted. Among the interviewees in the rural setting include indigenous (local) producers (farmers, wood carvers, shea butter producers) in the community. The interviewees comprised a large nuclear family of about fifteen adult members and other members of the community. Interviewees from the urban areas included government officials from the Technical Vocation and Education Training (TVET) Unit of the Ministry of Education, Accra; Council for Technical Vocation and Education Training (COTVET) also in Accra; three Rectors of three different polytechnics (now technical universities); two Regional Officers (Managers) of GRATIS Foundation centres, two Directors, each, from the Ministry of Environment, Science and Technology (MEST), and the Ministry of Trade and Industry (MoTI). In addition to the interviewees, one selfemployed entrepreneur and two shop owners, including a machinist were interviewed.

\section{Analysis of the ethnographic data}

Analysis of the corpus of textual data was done using the grounded theory techniques as postulated by Corbin and Strauss (2014) and 

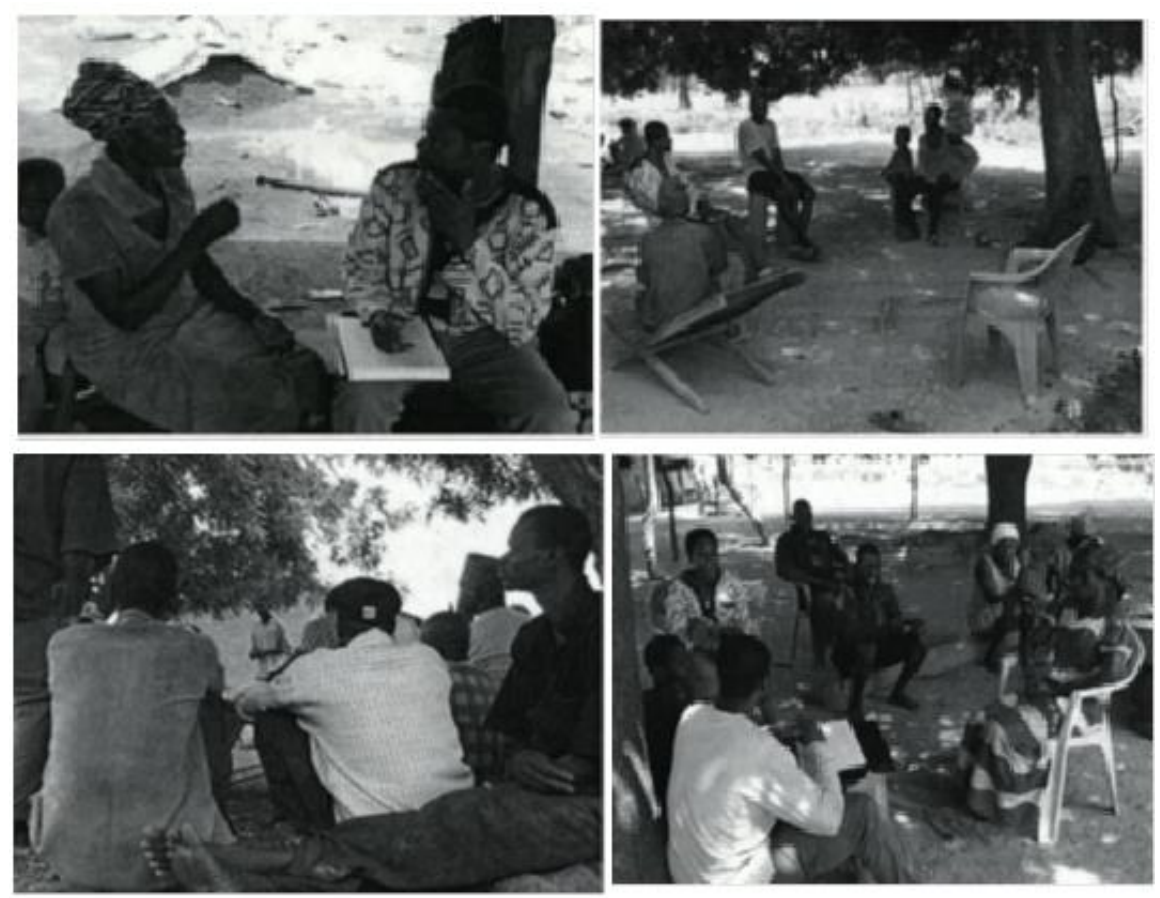

Figure 1. Extracting first hand indigenous knowledge from respondents. Source: Author's fieldwork.

in a constructivist's approach (Charmez 2003). Grounded theory is a social science research tool that possesses a rigorous analytical feature (Figure 2).

The analysis was done firstly by transcribing the interviews from the digital voice recording and secondly coding them into themes as they emerge from the data. Thirdly, the coded themes were sorted and similar themes categorised into thematic headings for discussion. By this process, the challenge of subjectivity in qualitative research is reduced.

The social science software package, NVivo, was used both to code and analyse the corpus of data. It was used to structure the coding process and retrieve the categorisation of the themes. Time and space will fail us to present the full analytical process here. Details of the analytical procedure used can be obtained from the afore-mentioned work of Donani (2014). The screenshot shown in Figure 2 is a sample representation of part of the NVivo coding and analytical process.

\section{FINDINGS, DISCUSSION AND WAY FORWARD}

This section presents the findings of the study constructed under thematic narratives from the data analysis of the in-vivo coding. It also attempts to provide a brief discussion on the findings and suggest the way forward. Among other things, it was found that there was a general understanding that Ghana was not industrialised but aspires to. Policy attempts to that effect have failed to yield expected results and lacked a focus on addressing the technology quest. The educational reforms implemented in Ghana with emphasis on TVET for academic and career progression were laudable, but yet to be directed towards industrial development. Below are some key findings as they emerge from the data analysis.

\section{Industrial development versus infrastructural development}

The idea of developing the national economy through industrial growth was a highly anticipated and entrenched concept among respondents. It was not uncommon to hear respondents (individuals and group) give such expressions as: "We could develop Ghana to be like Dubai; we will build technology park; we are going to establish the fourth industrial revolution". It came out that the idea of industrialisation was akin to infrastructural development in the mindset of respondents - a cultural anecdote. This finding reflects the work of Juma (2011), who, like the respondents, calls for provision of infrastructure to develop Africa's diminishing industrial base. The opinion expressed by respondents for Ghana to develop like Dubai was seen to be without due recourse to building the stalled industrial base for the lack 


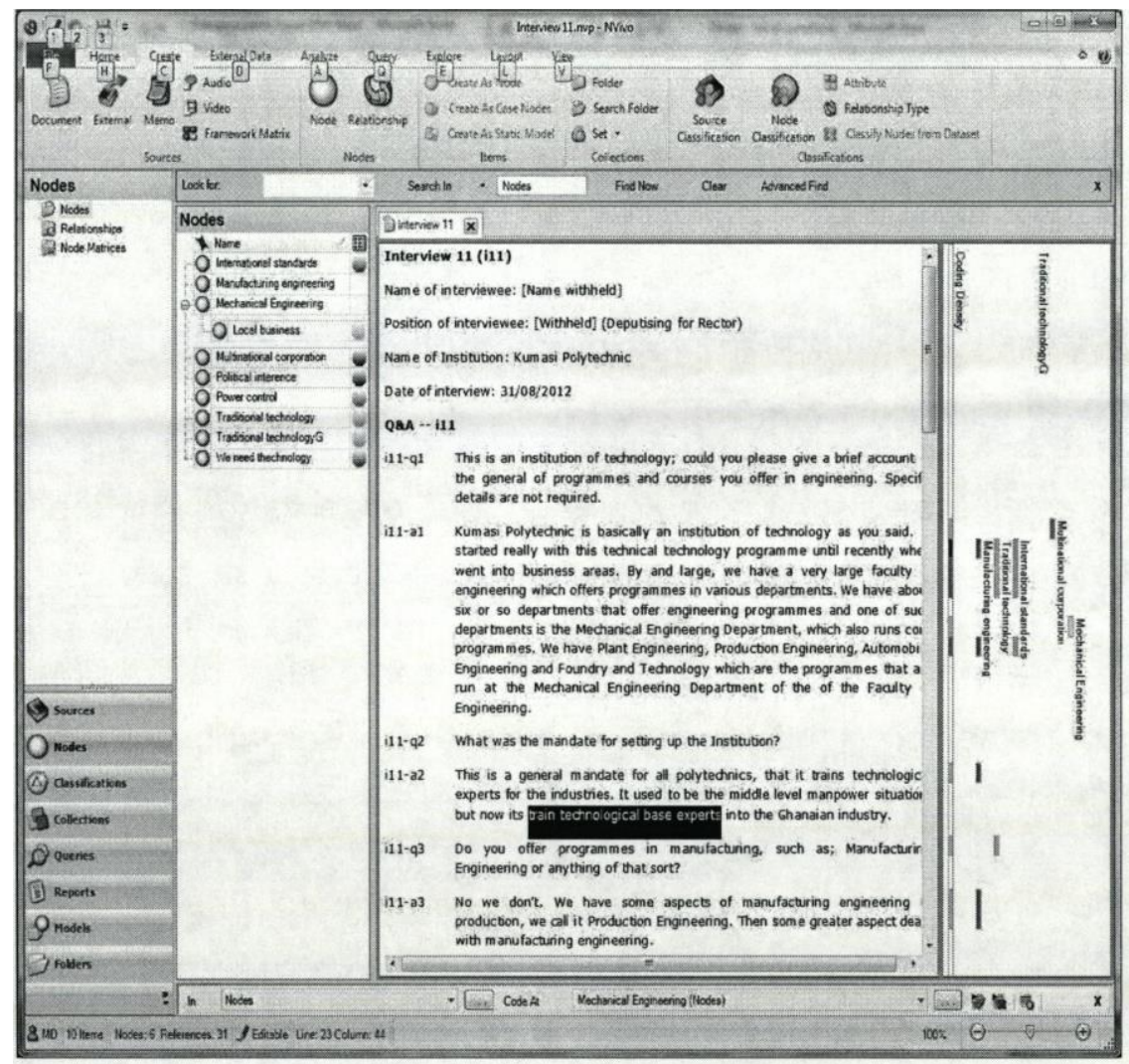

Figure 2. Screenshot Sample of data analysis using NVivo.

of technology development framework to feed the industry. Infrastructure is needed to enable industry to flourish and industry is also needed to generate the needed wealth with which to build the infrastructure. Having noted from literature that "African economies have de-industrialised" (ADB, 2019), it therefore suggests that infrastructure are wished for, without the necessary input to stimulate a strong industrial base to create the wealth needed to bring about the development and growth in infrastructure.

A suggested way forward is to have a national focus on industrialisation through development and deployment of needed production technologies to the industries. A clear framework for technology development for industry is needed. This makes technical education relevant to drive such a framework to reality.

\section{Indigenous production methods (IPM) and knowledge}

Ghana's indigenous production methods (IMP), as gathered from the ethnographic study, have remained rudimentary in practise ever since its historic application. Its use is preserved as a cultural heritage, thus, no extensive improvement has been accorded them for large scale industrial production. The work of Cruickshank and Richardson (2019) affirms this finding, seeing Ghana's advancement in industry has remained retrogressive in comparison with developing nations in other regions of the world. Stalled growth in development of indigenous knowledge and production processes include the local textile production from the traditional loom (referred to locally as kente and dagara-waja), methods of processing foods like palm oil, shea butter, pottery and local ceramics, etc. Local production methods have not received the needed institutionalised research for development. Where there has been some form of fabrication of implements and machines to aid in some section of IPM, their application is yet to receive a widespread deployment due to inherent cost beyond the reach of indigenous end-users and lack of research support. They therefore become uncompetitive at the global front as shown by scholars like Lall and Pitrobali (2002). 
A way forward is the need for a policy shift from the high dependence on importation of technical solutions (as in machines and equipment) to generating solutions from technical educational setups and research institutions. Also, government should allocate a percentage of national budget, at least, $5 \%$, on home grown technological solutions and research for industry. In addition, local industries need to be protected.

\section{Call for adoption of best practice syndrome}

Respondents sought to establish in Ghana best practices of policies successfully implemented in other parts of the world. This is viewed by this study as a form of neoimport substitution policy. Acclaimed best practices heralded by respondents are desired to be promoted in Ghana without due assessment of their adaptability to the Ghanaian culture and its inclination in a local content consideration. In line with the work of previous scholars, like Edgerton (2008) and Chevalier et al. (1992), development models and best practices which proved successful in other regions have failed to yield similar success results in African countries, of which Ghana is one. Ghana should therefore be cautious in adopting other practices without a complete ground work of cultural assimilation. Best practices from elsewhere are good; as such, should be studied for adoption possibility before implementation.

A way forward may be to provide proper assessment framework and modification of any best practices before adopting them. More so, streamlined best practices should be inculcated into the technical education curriculum development.

\section{Technology leapfrogging}

There was an expectation among respondents in the possibility of Ghana coming up to develop its industrial capability through technology leapfrogging. Respondents consistently demand for state-of-the-art technology to leapfrog, the industrial base. Government might therefore need to set up a leapfrogging strategy for industrial take off. It should however be recalled from literature that the world technological advancement is not static, but continuously evolving (Cruickshank and Richardson, 2019). Thus, as the technology trajectory of the developed world keeps advancing, for Ghana to maintain the leapfrogging strategy in a steady manner would mean continuously following in the shadows of the technology pacesetters. This is in exception where a "leap" is able to "land" ahead of the technology developers and maintain that leading role.

A way forward would be for Ghana to develop its technology base, while taking advantage of prevailing advancing technologies. This may require forming strategic partnerships with relevant global industry leaders to leverage on their expertise with linkage to technical institutions.

\section{Disconnection between academia and indigenous development in society}

A disconnection of formal education from application of traditional indigenous knowledge in Ghana was conspicuously visible. The knowledge and skill acquired in academic qualification conversely also lack a structure by which they could be disseminated into the culture or employed in developing or adding value to indigenous knowledge.

A way forward is to introduce indigenous production techniques into the technical educational curricula.

\section{Technical education and training}

An overview of the technical education curricula revealed high quality education and training being provided at the various levels of qualification. The training was also observed however to be more of service provision than component on product design and manufacture (excluding garment making and sculptures) to lead to fabrication of parts and construction of machines and equipment necessary for industry. IPMs were invisible in the curricular. Existing report, like CMEAU (2007), points to the rigidity in the educational setups. In the light of the industrialisation agenda, the rigidity in the educational setup will need to be studied.

A suggested way forward is to strengthen design and manufacturing in TVET curricula and some accepted level of flexibility in curricular design needs to be incorporated into the educational structure.

\section{Curriculum development challenge}

There was the challenge of developing new curriculum in the technical education system. Educationists, at the tertiary technical level, were met with resistances in proposing new curricula in a particular subject area. This again is in confirmation with literature on the rigidity in Ghana's educational system (CMEAU, 2007), despite the various educational reforms in the country.

A way forward may be to outline a clear structure and procedure for curriculum development and introduction of new academic programmes into technical educational system.

\section{Final year students' project work}

At the tertiary level, final year students' project works are 
hardly connected to industry, neither sponsored. Currently, no policy was found by this study to promote industry-based students' project work.

A suggested way forward is that, students' final year project work should be directed to solve some specific identified problem in the industry.

\section{Conclusion}

In conclusion, this study looked at the industrialisation challenge in Ghana (as a subset of the African situation of low industrialisation) and how technical education could be positioned to help resolve the impasse. It was established in this study that industrialisation was indeed a cultural affair, thus, an effort to create a cultural linkage through technical education became an interest. A soft operations research methodology of ethnography was therefore adopted for the study, to obtain firsthand information not controlled by assumptions and speculations. The corpus of data retrieved was processed by in-vivo coding for grounded theory analytical approach. The NVivo software package was therefore used in the analysis of the data.

The findings showed that Ghana's industrialisation policies were yet to deliver the expected outcomes. This study attributes the failure to the absence of culturalisation of Ghana's industrialisation intent in addition to other possible factors. The study sees technical education as a possible vehicle to provide the connecting force with indigenous methods of production.

Technical education is positioned to provide the needed human resource for both local industry and foreign investors. Supplying the needed human resource to mainly serve foreign investor industry, would place the national economy continuously on the fringe and fragile pathway as noted by previous scholars.

Higher roles are now expected of Technical Education to fuse education with production as a cultural heritage.

This therefore calls for a policy-shift to build a comprehensive technical and vocational education and training (TVET) curriculum with linkage to culture for industrial development in Ghana.

\section{CONFLICT OF INTERESTS}

The authors have not declared any conflict of interests.

\section{REFERENCES}

Ackah C, Adjasi C, Turkson F (2016). Industrial Policy in Ghana: Its Evolution and Impact. In: C. Newman, J. Page, J.R. and A. Shimeles, M. Söderbom, and F Tarp, eds. 2016. Manufacturing Transformation: Comparative Studies of Industrial Development in Africa and Emerging Asia. [Online]. Oxford Scholarship Online, Available at: htpps://www.oxfordschoalrship.com [Accessed 24 July, 2020].

Adam B, Cohen BA (2009). Many Forms of Culture. American
Psychological Association, Arizona State University 64:194-204.

African Development Bank (ADB) (2019). African Economic Outlook. Available at: https://www.afdb.org/en/news-and-events/africaneconomic-outlook-2019-africa-growth-prospects- [Accessed 28 July, 2020].

African Union (2007). Strategy to Revitalize Technical and Vocational Education and Training (TVET) in Africa. A report of the meeting of the Bureau of the Conference of Ministers of Education of the African Union (COMEDAF II+), at Addis Ababa, Ethiopia pp. 29-31.

Akubue A (2000). Appropriate Technology for Socioeconomic Development in Third World Countries.

Amankwah-Amoah J, Osabutey E, Egbetokun A (2018). Contemporary challenges and opportunities of doing business in Africa: The emerging roles and effects of technologies. Technological Forecasting and Social Change. ISSN 0040-1625.

Association for Manufacturing Technology (AMT) (2013). What is Manufacturing Technology? The Association for Manufacturing Technology (AMT). [Online]. Available at: http://www.amtonline.org/aboutamt/WhatisManufacturing Technology [Accessed 11 April 2013].

Aryeetey E, Fosu AK (2008). Economic Growth in Ghana: 1960-2000. In: J. B., Nudulu, J. -P., Azam, and H. R., Bates, eds. 2008, The Political Economy of Economic Growth in Africa, 1960-2000: Country Case Studies, Press, Cambridge, Cambridge University pp. 289-324.

Austin AR, Headrick D (1983). The Role Technology in the African Past. African Studies Review 26(3/4):163-184.

Barratt M, Choi T, Li M (2011). Qualitative Case Studies in Operations Management: Trends, Research Outcomes, And Future Research Implications. Journal of Operations Management 29(4):329-342.

Bernard HR (2013). Social Research Methods: Qualitative and Quantitative Approaches, Los Angeles, Sage Publications Inc.

Chakravorti B, Chaturvedi RS (2019). How technology could promote growth in 6 African countries, Harvard Business Review, [Online] Available at: https://hbr.org/2019/12/research-how-technology-couldpromote-growth-in-6-african-countries

Charmez K (2003). Grounded theory. Strategies of Qualitative Inquiry 2:249.

Chatelier G, Voicu L (2018). E-learning within the framework of UNESCO, Assupmtion University, Thailand.

Chevalier M, Taylor G, Carden F (1992). Redesigning Western Foreign Policy. In: J-M. Choukroun and R. M.Snow, eds. 1992. Planning for Human Systems: Essays in Honor of Russel L. Ackoff, Philadelphia, Busch Center.

Conference of Ministers of Education of the African Union (CMEAU) (2007). Strategy to Revatalize Technical and Vocational Education and Training (TVET) in Africa. Addis Ababa, African Union.

Collins CS, Stockton CM (2018). The Central Role of Theory in Qualitative Research. International Journal of Qualitative Methods 17(1):1609406918797475.

Corbin J, Strauss A (2014). Basics of qualitative research: Techniques and procedures for developing grounded theory, London, Sage publications.

Corbin JM, Strauss A (1990). Grounded theory research: Procedures, canons, and evaluative criteria. Qualitative Sociology 13:3-21.

Cossart B (2020). Review of the book The Gun in Central Africa: A History of Technology and Politics, by Giacomo Macola. Technology and Culture 61:968-970.

Council for Technical and Vocational Education and Training (COTVET) (2016). Manual for the Operationalisation of the National Technical and Vocational Education and Training Qualifications Framework (NTVETQF Manual), Council for Technical and Vocational Education and Training (COTVET).

Coughlan P, Coghlan D (2002). Action research for operations management. International Journal of Operations and Production Management 22(2):220-240.

Cruickshank JO, Richardson AE (2019). Ghana's industrial development history and impact of the technology gap. Conference on bridging the technology gap towards "Ghana beyond aid" and Youth employment. Held from January 21 to 25, 2019 at Peduase Valley Resort, Perduase.

Davidson B, Buah FK, Ajayi JFA (1965). The growth of African 
Civilization: A history of West Africa 1000-1800, London, Longman Group Limited.

Donani YM (2014). Developing a framework for sustainable manufacturing of technologies in Africa focusing on Ghana. PhD thesis, University of Nottingham. Access from the University of Nottingham repository: Available at: http://eprints.nottingham.ac.uk/37127/1/690901.pdf . [Accessed 2 March 2017].

Donani YM (2015a). Technology development framework for Ghana: the role of Technical and Research Institutions. International Journal of Development Research 5(1):2852-2857.

Donani YM (2015b). Ethnographic Study to Understand the Culture of Technology Manufacturing in Ghana. International Journal of African Development 2(2):36-46.

Donani Y-M, Clifford M, Raman S, Apeagyei AK (2017b). Cultural assimilation of technology development in Ghana: An ethnographic approach, African Journal of Technical Education and Management 1(1):53-70.

Donani YM, Kugblenu HA, Fuseini AB (2017a). A framework towards technology creation in Africa: focusing on Ghana. International Journal of African Development 4(2):6.

Economywatch-Content (2010). Africa Economy [Online]. Available: http:L/www.economywatch.com/worldeconomyafrica [Accessed 19 February 2011].

Edgerton D (2008). The Shock of the Old: Technology and Global History since 1900, London, Profile Books Ltd.

Effah P (2017). The Role of the New Technical Universities in the Improvement and Implementation of Technical Vocational Education and Training (TVET) in Ghana. African Journal of Technical Education and Management 1:85-95.

Gertler MS (2004). Manufacturing Culture: The Institutional Geography of Industrial Practice, OUP Oxford.

Gibbs GR (2008). Analysing qualitative data, SAGE Publications Limited.

Government Of Ghana (GoG) (2010). Medium-Term National Development Policy Framework: Ghana Shared Growth and Development Agenda (GSGDA) 2010-2013. Accra-Ghana: National Development Planning Commission (NDPC).

Hofstede G (1984). Cultural Dimensions in Management and Planning. Aisa Pacific Journal of Management 1(2):81-99.

Hofstede G (2011). Dimensionalizing cultures: the Hofstede model in context. Online Readings in Psychology and Culture 2:1-26.

Hofstede G (2013). Welcome to the site of Geert and Gert Jan Hofstede This is Geert's only website. [Online]. Available: www.geerthofstede.com/index [Accessed January 2013].

Juma C (2011). The New Harvest: Agricultural Innovation in Africa, New York, Oxford University Press.

Khalil TM (2000). Management of Technology: The key to competitiveness and wealth creation, New York, McGraw Hill Science, Engineering \& Mathematics.

Kiridena SB, Fitzgerald A (2006). Case study research in operations management. ACSPRI Social Science Methodology. Conference pp. 1-18. Sydney: ACSPRI.

Lall S, Kraemer-Mbula E (2005). Industrial Competitiveness in Africa: Lessons from East Asia, Bourton-on-Dunsmore, ITDG Publishing.

Lall S, Pitroballi C (2002). Failing to Compete: Technology Development and Technology Systems in Africa, Cheltenham, Edward Eglar.

Mayer J (2004). Industrialization in developing countries: Some evidence from a new economic geography perspective, No. 174, August 2004 August 2004, available at: https://unctad.org/en/Docs/osgdp20048_en.pdf [Accessed: 29th May, 2019].

Ministry of Education (MoE) (2014). Report of the Technical Committee on Conversion of the Polytechnics in Ghana to Technical Universities.
Ministry of Trade and Industry (MoTI) (2009). The Republic of Ghana: Ghana Industrial Policy, The Ministry of Trade and Industry, Accra, Ghana. [Hanna S. Tetteh, Hon. Minister of Trade and Industry]. ((n.d.) i.e. no date; nearest date: 2009)

Ndiaya C, Lv K (2018). Role of Industrialization on Economic Growth: The Experience of Senegal (1960-2017).

Nyarko DA (2011). Polytechnic Education in Ghana: The Challenges and rospects, An address by Rev. Prof. Daniel A. Nyarko (Rector Takoradi Polytechnic) on the occasion of the NABPTEX/Polytechnics meeting, Accra, $23^{\text {rd }}$ arch, 2011.

Oketch MO (2007). "To vocationalise or not to vocationalise? Perspectives on current trends and issues in technical and vocational education and training (TVET) in Africa." International Journal of Educational Development 27(2):220-234.

Oxford Business Group (2020). Industrialisation and diversification efforts in Ghana target value-added exports. The Report: Ghana 2018. [Online]. Available at: hppts://oxfordbusinessgroup.com [Accessed 24 July, 2020].

Pelto GH (2020). Applying focused ethnographic methods: examining implications of intracultural diversity for nutrition interventions. Nutrition Reviews 78(Supplement_2):71-79.

Portes A (1976). On the Sociology of National Development: Theories and Issues. American Journal of Sociology 82(1):55-85.

Seagriff T, Lord S (2008). Soft Operations Research Techniques: Current and future uses. Defence Science and Technology Laboratory pp. 40-53.

Signé L, Johnson C (2018). The potential of manufacturing and industrialization in Africa Trends, opportunities, and strategies, African Growth Initiative, Brookings Institute, Stanford University.

Simon HA, Newell A (1958). Heuristic problem solving: The next advance in operations research. Operations Research 6:1-10.

Slack N, Chambers S, Johnston R (2010). Operations Management. Essex, Pearson Education Limited.

Szogs A, Cummings A, Chaminade C (2009). Building systems of innovation in less development countries: The role of intermediate organizations. [Online]. Available: http:L/smartech.gatech.edulj_s_pui/bitstream/1853/36627/1/1237973 164 AS.pdf [Accessed 19 November 2011].

Teal F (1998). The Ghanaian Manufacturing Sector 1991-1995: Firm growth, productivity and convergence. The Centre for the Study of African Economies Working Paper Series, Paper 81.

Tortorella GL, de Castro Fettermann D, Frank A, Marodin G (2018). Lean manufacturing implementation: leadership styles and contextual variables, International Journal of Operations and Production Management 38:1205-1227. [Online]. Available at: https://iranarze.ir/wp-content/uploads/2018/04/E6715-IranArze.pdf.

UNESCO (2010). World Data on Education: Ghana, VII Ed. ( $7^{\text {th }}$ edition) 2010/11 [Online]. Available at http://www.ibe.unesco.org/en/document/world-data-educationseventh-edition-2010-11. [Accessed 15 April, 2021].

UNESCO-UNEVOC (2012). "What is TVET?". Retrieved 6 June, 2014. http://www.unevoc.unesco. org/go.php?q=What+is+TVET.

UNIDO (2017). Industrial Development Report 2018. Demand for Manufacturing: Driving Inclusive and Sustainable Industrial Development. Vienna. [Online]. Available at: https://www.unido.org/resources-publications-flagship-publicationsindustrial-development-report-series/industrial-development-report2018. [Accessed: 5 February, 2021].

Wolcott HF (1990). Making a study more ethnographic". Journal of Contemporary Ethnography 19(1):44-72. 